\title{
THE PERSONAL LIABILITY OF STOCKHOLDERS IN AN UNREGISTERED FOREIGN CORPORATION.
}

As far as the writer has been able to discover, there is no reported case which directly settles the question of the extent to which stockholders of a corporation are liable for its debts in a state in which they have not complied with the conditions imposed upon foreign corporations doing business therein. The courts of the various states have passed upon the status of the foreign corporation itself, but they have left untouched the question above suggested. Their attitude towards a delinquent foreign corporation is somewhat curious. In some jurisdictions they refuse to recognize its contracts at all, while in others they hold that the right to enforce them is held in abeyance until the corporation shall have complied with the statutes of the state.

An article in 51, Central Law Journal, I04, classifies the statutes governing foreign corporations as follows:

I. Those which are prohibitory in form, with a penalty for their violation;

2. Those which are prohibitory in form, but without a penalty for their violation; and

3. Those which are not prohibitory in form, but which provide a penalty for their violation.

I must confess that in those states having statutes coming within the third class above mentioned, the point I raise in this article can have no merit; but where statutes of the first or second class govern, the result for which I contend must necessarily follow. The Pennsylvania Act of Assembly of April 22, I874, P. L. I08, is an admirable example of the statutes coming within the first class. For the sake of direct example, therefore, let us take the case of a corporation organized under the laws of another state, and attempting to do business in Pennsylvania, without having complied with the provisions of that act. It provides as follows:

Section I. No foreign corporation shall do any business in this commonwealth, until said corporation shall have 464 
established an office or offices, and appointed an agent or agents for the transaction of its business therein.

SEC. 2. It shall not be lawful for any such corporation to do any business in this commonwealth, until it shall have filed in the office of the secretary of the commonwealth a statement under the seal of said corporation, and signed by the president or secretary thereof, showing the title and object of said corporation, the location of its office or offices, and the name or names of its authorized agent or agents therein; and the certificate of the secretary of the commonwealth, under the seal of the commonwealth, of the filing of such statement, shall be preserved for public inspection, by each of said agents, in each and every of said offices.

SEC. 3. Any person or persons, agent, officer or employe of any such foreign corporation, who shall transact any business within this commonwealth for any such foreign corporation, without the provisions of this act being complied with, shall be guilty of a misdemeanor, and upon conviction thereof shall be punished by imprisonment not exceeding thirty days, and by fine not exceeding one thousand dollars, or either, at the discretion of the court trying the same.

Let us suppose that A., B. and C. compose the corporation; that $A$. and $B$. are the real persons carrying on the business; and that $\mathrm{C}$. is merely a member, holding one share of stock, and not participating in any way in the active work of the company. We shall assume that $\mathrm{A}$. orders goods from $X$., in the name of the corporation; that the goods are delivered to it, and charged to it upon the books of $\mathrm{X}$. When he presents his bill, he is told that the company has no assets; that the bill cannot be paid; and that, if he choose, he may file a petition in bankruptcy, but that such action will merely result in useless expense upon his part. Surely, this is a most aggravating state of affairs. He feels that he is being unfairly treated. He learns, for the first time, that the corporation has not registered in Pennsylvania, and he naturally wants to know what is to be done. Certain very able lawyers maintain that his only remedy is to enforce the penalty imposed in the third section of the act, and have the offenders arrested and fined; but he wants the price of his goods, not revenge. The writer contends, that, under this 
state of affairs, not only A. and B., but also C., may be held liable for the debt, either as individuals or as partners.

It is well settled that a corporation has no existence, as of right, outside of the state that created it. (Paul v. Virginia, 8 Wall. 168.) It is merely a creature of that state, and is recognized elsewhere only by comity. Despite, however, Mr. Chief Justice Marshall's definition, a corporation is not a fictitious entity. It is simply an aggregation of individuals, authorized by the state to act as one, and having certain specified immunities from personal responsibility for the debts of the combination. The deeper thinkers among writers on corporation law are gradually approaching the point where they will agree upon this definition; and I venture to prophesy that before many years, it will be accepted as the only true definition of a corporation. It is surely more consistent with the actual facts; and it does not depend upon any fiction of law for its support. Properly understood and applied, it will aid materially in a correct understanding of corporation law.

Granting that the decision in Paul v. Virginia be still the law, it naturally follows that if the corporation attempt to do business in a foreign state, without having first complied with the laws of that state regulating foreign corporations, its members cannot be doing business as a corporation. This deduction is made clearer if we consider it in the light of the definition given above. The stockholders are joint owners of the business; and therefore, in jurisdictions whither they cannot bring their corporate immunities, they can only be co-partners, as far as the rights of third persons are concerned. The privilege of acting as a unit, together with the immunities consequent thereupon, ceases with the authority of the sovereignty granting it. The Pennsylvania statute, and similar acts in other states, say that no foreign corporation shall do business therein, until it shall have complied with the specified requirements. The business, however, is done - that cannot be denied. If the corporation cannot do it; if the stockholders do not bring their acquired entity over the state line, then their agents do it; and the agents do it, not for themselves alone, but for their associates or principals, as the case may be. The agents do not hold 
themselves out as being the debtors, but refer to the corporation for which they profess to act. They are clothed by the stockholders with power to contract in the corporate name; which authority makes the stockholders liable. In other words, a body of men in a certain state are empowered to act as one. They come into another state where that unity is not recognized unless certain conditions precedent are performed. Can any conclusion be logically reached, other than that they are liable jointly and severally for the debts contracted by or for them in the business in which they are jointly engaged?

At this point, people are liable to ask whether a state does not, by comity, recognize the corporations of other states: to which I cheerfully give an affirmative reply, qualifying that reply, however, by the statement that such recognition is given only in the absence of prohibitory legislation by the state to which such corporations migrate, or in the absence of some principle of public policy therein to the contrary. All the cases upon this point, from the leading case of Bank of Augusta v. Earle, I3 Pet. 519, down to those of the present day, recognize this qualification. (See also Leasure v. Insurance Company, 9I Pa. 49r.) In fact, in the absence of legislation to the contrary, the courts will even recognize the limited liability of special partners under the laws of foreign countries, and will enforce the rights of such partners. (Barrows v. Dozens, 9 R. I. 446; King v. Sarria, 69 N. Y. 24.)

One of the cases upon this point (Demarest v. Flack, r28 N. Y. 205, decided in I89I) is interesting in this discussion, because the plaintiff therein tried to do the very thing that it is here claimed can be done under proper conditions-only the plaintiff therein did not have the proper conditions. It appears, from the statement of facts, that Flack, together with certain other persons, all citizens of the State of New York, obtained a charter of incorporation from the State of West Virginia, and under that charter proceeded to carry on the business of an amusement company in New York Cty. One of the amusements was a toboggan slide, down which the plaintiff was consumed with an ambition to slide. She 
therefore paid her money, took her position upon the toboggan, and started on the trip. Before the journey ended, a catastrophe happened, and she was injured. She sued the defendants jointly, as a joint stock company, and on the trial attempted to prove a partnership liability upon their part; alleging that the fact of citizens of New York having gone to a foreign state, and having incorporated there for the sole purpose of carrying on a business in New York, was a fraud against the laws and policy of the latter state, and, therefore, that statecould not recognize the defendants as a corporation, but must consider them as partners. The court held, however, that the defendants were legally incorporated in West Virginia, and that the mere fact of their preferring a charter from that state to one from their own, was not an evidence of fraud upon the State of New York; and that there being no other reason for not recognizing them as a corporation, they must be considered as having such privileges.

It appears, therefore, from these cases, that a corporation is allowed to do business outside of the state of its creation, merely as a matter of grace, and not as a matter of right. This principle is clearly stated in List v. Commonwealth, I I8 Pa. 332, which reaffirmed the doctrine of Paul v. Virginia, and recognized the fact that corporations are merely "creatures of local law and have not even an absolute right of recognition in other states."

The case which most nearly approaches the contention of this thesis is Lascher v. Stimson, I $45 \mathrm{~Pa}$. 30 , decided in I892. In that case, Lascher had supplied goods and had performed work for the Sudsena Manufacturing Company, a New Jersey corporation carrying on business in Pennsylvania, without having complied with the requirements of the Act of 1874 , above quoted. He had charged these items on his books, to the company, and was given in payment two notes, signed, "Sudsena Manufacturing Co., H. D. Stimson, Treasurer." His dealings had all been through Stimson; and when the notes fell due and were not paid, he chose, for reasons best known to himself, to ignore the corporation and to sue Stimson; and the Supreme Court of Pennsylvania held that compliance with the Act of 1874 was a condition 
precedent to the existence of the corporation in that state, and that Lascher had properly sued Stimson.

The writer has heard it contended that Stimson was held liable solely because he was the agent of the company; but this is absurd on the face of it, for an authorized agent, acting on behalf of a disclosed principal is never liable apon an ordinary written contract not under seal, unless his principal does not exist or cannot contract. The Sudsena Manufacturing Company did exist in New Jersey and could contract there. It was merely unauthorized to do business in Pennsylvania. But taking the case in the light most favorable to those who fondly, yet foolishly, cling to the agency theory, we find nothing in the decision which would exclude the contention that the principals, if sued, would have been held liable. A disclosed principal is always liable upon the contracts made in his name by his duly authorized agent; and where this principal consists of a number of stockholders, who have neglected to bring with them their shield of corporate entity, they are in no better position than the corporation would have been had it registered. It would have been liable as principal; so must they.

Another favorite objection is that the act prescribes its own penalty for non-compliance with its provisions; and that there is no remedy beyond this. But a little careful attention will effectually dispose of this error. The penalty is simply the remedy of the commonwealth against those who violate the act. It is the price which they must pay to the state for contempt of her laws. The act expressly states that "no foreign corporation shall do any business in this commonwealth" until it shall have complied with the statute, thus making an absolute condition precedent: and then it goes further, and provides that agents or officers presuming to act for such a delinquent corporation shall be liable to fine and imprisonment. There are two distinct provisions, neither of which is dependent upon the other. The condition precedent is expressed with sufficient clearness, and I do not see how it can be successfully evaded. For this reason, I maintain that in those jurisdictions having prohibitory statutes without a penalty annexed, the argument herein stated applies; because the vital part of the statute is its prohibitory feature, its evident purpose to exclude for- 
eign corporations entirely until they shall have complied with the conditions precedent: and also for this reason, I do not think that my argument applies in those jurisdictions in which the statutes are merely penal and not prohibitory; because the penalty is merely a punishment, and there is no expressed purpose to exclude the corporation.

If the corporation goes into a foreign state to do business, its stockholders are bound, at their peril, to see that the laws of that state are observed. Incorporation, and the immunities stockholders gain thereby, are special privileges, hedged about with conditions. If the stockholders desire to avail themselves of the privileges, they must observe the conditions. This is the underlying principle of incorporation, and is supported by all the authorities.

The fact that $X$., in the supposititious case above suggested, gives credit to the company, does not alter the liability of the stockholders; because that credit was given under a false impression, created by them, that they were a corporation. He deals with men whom he believes to be acting in accordance with law. There is nothing to put him upon inquiry as to the truth or falsity of that belief, and the stockholders cannot take advantage of their own wrong or neglect to clothe themselves with privileges and immunities, which are merely matters of grace and not of right. 